\title{
Knowledge on HBV vaccine
}

\author{
Asres Bedaso ${ }^{1 *} \mathbb{E}$, Bereket Duko ${ }^{1}$ and Remla Fedlu²
}

\begin{abstract}
Objectives: The study was conducted to assess the knowledge on HBV vaccine and vaccination status among health care workers of Hawassa University Comprehensive Specialized Hospital.

Result: From the total 258 questionnaire prepared for the study participant, data was collected from 241 participants making the response rate of $93.4 \%$. Regarding socio-demographic characteristics of respondents 98 (40.7\%), and 159 $(66 \%)$ were females and Bachelor of Science graduates respectively. Only 73 (30.3\%) respondents reported that they are vaccinated for hepatitis B vaccine. But only 16 (21.9\%) received three doses of Hepatitis B vaccine, which was 6.6\% of the total health care workers. More than half $146(60.6 \%)$ of the respondents had good knowledge about hepatitis $B$ virus infection and 120 (49.8\%) had good knowledge about hepatitis B vaccine. Regarding knowledge about hepatitis B virus infection prevention and control methods, 131 (28.5\%) of the respondents have good knowledge.
\end{abstract}

Keywords: HBV, Knowledge, Vaccination status, Health care worker

\section{Introduction}

Hepatitis is an inflammation of the liver due to viral infections and there are groups of viruses that affect the liver. Hepatitis B virus (HBV) infection threatens the health of populations across the globe. It is a DNA virus that cause viral hepatitis and can lead to liver cirrhosis and hepatocellular carcinoma $[1,2]$.

An estimated 240 million people are chronically infected and more than 780,000 people die every year due to complications of hepatitis B including cirrhosis and liver cancer [3]. The spectrum of clinical manifestations of hepatitis B virus (HBV) infection varies in both acute and chronic disease. During the acute phase, manifestations range from sub clinical or anicteric hepatitis to

\footnotetext{
*Correspondence: asresbedaso@gmail.com

${ }^{1}$ College of Medicine and Health Sciences, School of Nursing, Hawassa University, Hawassa, SNNPR, Ethiopia

Full list of author information is available at the end of the article
}

icteric hepatitis; during the chronic phase manifestations range from asymptomatic carrier state to chronic hepatitis, cirrhosis and hepatocellular carcinoma [4].

The World Health Organization estimates that about 2 million health care workers face occupational exposure to $\mathrm{HBV}$ each year and $90 \%$ of the infections that result from these exposures are in low-income countries, especially those in sub-Saharan Africa [5].

Liver diseases are common in Africa and account for high morbidity and mortality. Reports from hospital based studies show that about $12 \%$ of medical admissions and more than $20 \%$ of hospital mortality in many parts of Africa were due to acute viral hepatitis, chronic hepatitis, cirrhosis and hepatocellular carcinoma. Chronic carrier rates among the general population in Nigeria ranged from about $12 \%$ to $48.7 \%$ in different states and cities [6].

Ethiopia, being part of sub-Saharan region, is ranked as an area with medium to high endemicity for $\mathrm{HBV}$ 
infection, based on previous population surveys [7]. Ethiopia, which has significant Hepatitis B transmission in both children and adults displays around 6\% to $12 \%$ hepatitis B surface antigen ( $\mathrm{HBs} \mathrm{Ag}$ ) prevalence. Liver disease is known to be a significant cause of hospital admission in Ethiopia although the etiology of this disease is not well defined. Acute viral hepatitis, chronic hepatitis and cirrhosis of the liver account for $12 \%$ of hospital admissions and 31\% of mortality on medical wards in Ethiopia [8].

Hepatitis B infection is a major public health problem in Ethiopia and health care workers are also at increased risk of acquiring hepatitis $B$ infection due to occupational exposure $[9,10]$. Therefore, the aim of this study is to assess the knowledge about hepatitis $B$ vaccine and vaccination status among health care workers of Hawassa University Comprehensive Specialized Hospital.

\section{Main text \\ Methods}

\section{Study design, study area and period}

Facility based cross-sectional study design was conducted from Feb 3, 2017 to May 29, 2017, among health care workers of Hawassa University Comprehensive Specialized Hospital. Hawassa University Comprehensive Specialized Hospital is found in Hawassa city, $273 \mathrm{~km}$ far south from Addis Ababa. The hospital started giving service since 2005 and serves for more than 18 million people of the catchment area. The hospital had more than 400 beds for inpatient service and also gives different outpatient services.

\section{Sample size determination and sampling procedure}

Sample size of this study was determined using single population proportion formula by considering $95 \%$ level of confidence, $5 \%$ margin of error and proportion of health care workers (HCWs) who were knowledgeable about hepatitis B vaccine $62 \%$ is considered [17]. Since the sampling frame is less than 10,000 , correction formula was used. After adding $10 \%$ none response rate, the final sample size was 258. Considering list of health care workers as a sampling frame, which we get from the hospital human resource development office, Simple random sampling technique was used to select eligible study participants from the hospital.

\section{Source and study population}

All health care workers working in Hawassa University Comprehensive Specialized Hospital were the source population. Health care workers working in Hawassa University Comprehensive Specialized Hospital who are available during data collection period were considered as source population.

\section{Data collection technique and instrument}

Self-administered technique was used to collect data from selected study participants. The questionnaire had three parts; the first part contains socio-demographic characteristics of HCWs, the second part was knowledge of HCWs on hepatitis B vaccine. Level of knowledge of HCWs was categorized based on the mean value; those who scored below the mean were classified as less knowledgeable and those who scored above the mean were classified knowledgeable. The third part was about hepatitis B vaccine status of HCWs. Before data collection pretest was done at Adare Hospital to test the reliability of the tool on $5 \%$ of the sample size.

\section{Data analysis}

The collected data was entered and analyzed using Statistical Package for Social Sciences (SPSS 20). Then, data was edited, coded, cleaned and some consistency checks were made to have quality data.

\section{Result}

From the total 258 questionnaires prepared for the study participant 241 responded and include in the analysis making the response rate of $93.4 \% .98$ (40.7\%) of respondents were females and 117 (48.5\%), 45 (18.7\%) and 33 (13.7\%) of the respondents were nurses, physician and midwifes by their occupation respectively. Regarding educational level of the respondent's; majority 159 (66\%) of them had Bachelor of Science degree (Table 1).

\section{History of ever occupational exposure to conditions that predisposed to $\mathrm{HBV}$ infection}

Regarding exposure to conditions that might lead to HBV infection 153 (63.5\%) of the participant reported that they had history of exposure to blood or body fluids on intact skin (Table 2).

\section{Knowledge about hepatitis B infection}

Study participants were asked about their knowledge about hepatitis B infection using 8 item tool. The minimum and the maximum score to the question were 1 and 8 respectively. The mean knowledge score for HBV infection was $6.63(\mathrm{SD} \pm 0.9)$.

Finally the overall category of the study participants showed that more than half 146 (60.6\%) of the respondents had good knowledge about hepatitis B infection (Table 3).

\section{Knowledge of hepatitis B infection prevention and control measures}

Respondents were asked 14 questions about hepatitis $\mathrm{B}$ infection. The maximum and minimum scores were 
Table 1 Socio demographic characteristics of health care workers at Hawassa University Comprehensive Specialized Hospital, Hawassa, SNNPR, Ethiopia, 2017

\begin{tabular}{|c|c|c|}
\hline Socio demographic characteristic & Frequency & Percent \% \\
\hline \multicolumn{3}{|l|}{ Sex } \\
\hline Male & 143 & 59.3 \\
\hline Female & 98 & 40.7 \\
\hline \multicolumn{3}{|l|}{ Occupation } \\
\hline Physician & 45 & 18.7 \\
\hline Nurse & 117 & 48.5 \\
\hline Midwife & 33 & 13.7 \\
\hline Laboratory technician & 20 & 8.3 \\
\hline Pharmacists & 5 & 2.1 \\
\hline Dentist & 1 & 0.4 \\
\hline Medical specialist & 10 & 4.1 \\
\hline Surgical specialist & 8 & 3.3 \\
\hline Other & 2 & 0.8 \\
\hline \multicolumn{3}{|l|}{ Marital status } \\
\hline Single & 149 & 61.8 \\
\hline Married & 89 & 36.9 \\
\hline Windowed & 1 & 0.4 \\
\hline Divorced & 2 & 0.8 \\
\hline \multicolumn{3}{|l|}{ Department } \\
\hline Outpatient department & 22 & 9.1 \\
\hline Emergency room & 45 & 18.7 \\
\hline Operation room & 32 & 13.3 \\
\hline Delivery room & 27 & 11.2 \\
\hline Ward & 98 & 40.7 \\
\hline Other & 17 & 6.9 \\
\hline \multicolumn{3}{|l|}{ Educational level } \\
\hline Diploma & 46 & 19.1 \\
\hline Degree (B.Sc.) & 159 & 66 \\
\hline Master degree & 10 & 4.1 \\
\hline Other & 26 & 10.8 \\
\hline \multicolumn{3}{|l|}{ Working duration (years) } \\
\hline$<5$ & 203 & 84.2 \\
\hline$\geq 5$ & 38 & 15.8 \\
\hline \multicolumn{3}{|l|}{ Vaccination status } \\
\hline Yes & 73 & 30.3 \\
\hline No & 168 & 69.7 \\
\hline \multicolumn{3}{|l|}{ No of HBV dose taken } \\
\hline One time & 34 & 46.6 \\
\hline Two time & 23 & 31.5 \\
\hline Three time & 16 & 21.9 \\
\hline
\end{tabular}

14 and 7 respectively. The mean score of the respondents about hepatitis B infection prevention and control method was 12.29 with standard deviation of 1.7 and $131(28.5 \%)$ of the respondents scored above the mean (Additional file 1).
Table 2 History of ever occupational exposure to conditions that predisposed to HBV infection of health care workers at Hawassa University Comprehensive Specialized Hospital, Hawassa, SNNPR, Ethiopia, 2017

\begin{tabular}{lc}
\hline Question & Yes, number (\%) \\
\hline $\begin{array}{l}\text { History of exposure to blood or body fluids on intact } \\
\text { skin }\end{array}$ & $153(63.5)$ \\
$\begin{array}{l}\text { History of splash of blood or body fluids to eye or } \\
\text { mouth }\end{array}$ & $81(33.6)$ \\
$\begin{array}{l}\text { History of splash of blood on cuts or unprotected skin } \\
\text { Ho (23.7) }\end{array}$ & 57
\end{tabular}

\section{Knowledge of hepatitis B vaccine}

Respondents were asked 12 item questions to assess their knowledge about Hepatitis $B$ vaccine. The maximum and minimum scores for the questions were 11 and 3 respectively. The mean knowledge score for hepatitis B vaccine was 7.54 with standard deviation of 1.74 . Overall, the assessment of knowledge of respondents about Hepatitis B vaccine indicates 120 (49.8\%) had good knowledge about the hepatitis $B$ vaccine (Additional file 2).

\section{Discussion}

Health care workers are at risk of acquiring blood born disease including HBV due to occupational exposure to blood and body fluids $[9,10]$. From 241 Health Care Workers (HCWs) who responded the question whether they had history of occupational exposure to blood or body fluid on intact skin or not, 153 (63.5\%) reported history of occupational exposure. This indicates there is high level of occupational exposure to hepatitis B and other blood borne pathogens.

This study also assessed that $30.3 \%$ of study participants were vaccinated and Out of the vaccinated 73 respondents, only 16 (21.9\%) were fully vaccinated. This finding is higher than the study conducted in Bahirdar [17] where only $10 \%$ were vaccinated and out of which only $5.4 \%$ were fully vaccinated. The result in the current study is very low in comparison to other studies conducted in Burkina Faso [16] where 58.6\% were partially and $10.9 \%$ were fully vaccinated, Nigeria [12] $65 \%$ vaccinated, Syria [13] 76.6\%, Morocco [11], 55\%, north India [15] $60 \%$ partially and $40 \%$ fully vaccinated, Greece [14] $57.1 \%$ were vaccinated and USA [13] $75 \%$ were fully vaccinated. The variation might be due to the difference in health system of the countries, availability and accessibility of the vaccine.

The finding in the current study indicates that 146 (60.6\%) of the study participants had good knowledge about HBV infection which is lower than the finding of 
Table 3 Knowledge of health care workers about hepatitis B infection at Hawassa University Comprehensive Specialized Hospital, Hawassa, SNNPR, Ethiopia, 2017

\begin{tabular}{lr}
\hline Knowledge question about hepatitis B infection & True, N (\%) \\
\hline One can get hepatitis B infection through needle stick injury & $235(97.5)$ \\
Hepatitis B infection can be prevented by vaccination & $233(96.7)$ \\
Hepatitis B virus can be found in semen or vaginal fluid of infected person & $225(93.4)$ \\
Hepatitis B infected person may be asymptomatic for long time & $218(90.5)$ \\
Every person exposed to hepatitis B virus will develop acute hepatitis immediately & $81(33.6)$ \\
Hepatitis B virus is highly infectious & 226 (93.8) \\
Only small proportion of the world population is infected with hepatitis B virus & $79(32.8)$ \\
Hepatitis B virus mainly affects live & $217(90)$
\end{tabular}

the study conducted in Nigerian Lagos State [18] where $70.2 \%$ of study participant were knowledgeable about HBV infection. But the finding of this study is higher than the study conducted in Addis Ababa [8] where $55.1 \%$ of study participants had good knowledge about HBV infection. The variation might be due to the difference in health system.

Regarding knowledge about hepatitis B vaccine, in this study $40.9 \%$ of study participants had good knowledge about Hepatitis $B$ vaccine which is lower than the study conducted in Nigeria [12] where $77 \%$ of study participants were knowledgeable about the vaccine. The difference might be due to the variation among health care workers, where in some countries training and orientation was given for HCWs.

\section{Conclusion}

More than half of study participants found to have poor knowledge about HBV. This study also found that the vaccination status of respondents to be very low and when we consider the long term severity of the disease and the increased exposure risk of health care workers, it is better to avail and provide hepatitis $B$ vaccine for health care workers as a work place safety.

\section{Limitation}

The cross sectional nature of the present study prevents any causal inferences.

\section{Additional files}

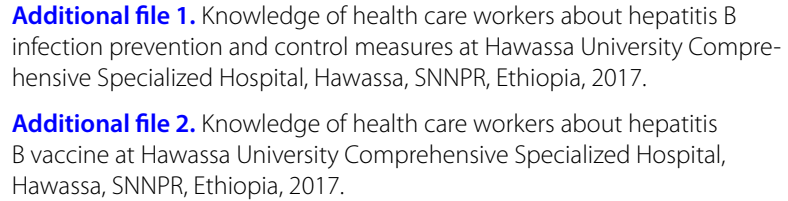

Additional file 1. Knowledge of health care workers about hepatitis B infection prevention and control measures at Hawassa University Comprehensive Specialized Hospital, Hawassa, SNNPR, Ethiopia, 2017.

Additional file 2. Knowledge of health care workers about hepatitis $B$ vaccine at Hawassa University Comprehensive Specialized Hospital, Hawassa, SNNPR, Ethiopia, 2017.

\section{Abbreviations}

DNA: deoxyribonucleic acid; HBs Ag: hepatitis B surface antigen; HBV: hepatitis B vaccine; HCWs: Health Care Workers; SPSS: Statistical Package for Social Science.

\section{Authors' contributions}

$A B, B D$ and $R F$ participated in the conception, design of the study, reviewing proposal and data analysis. $A B, B D$ and $R F$ participated in reviewing and writing the report. $A B$ prepared the manuscript for publication. All authors read and approved the final manuscript.

\section{Author details}

${ }^{1}$ College of Medicine and Health Sciences, School of Nursing, Hawassa University, Hawassa, SNNPR, Ethiopia. ${ }^{2}$ Hawassa University Comprehensive Specialized Hospital, Hawassa, SNNPR, Ethiopia.

\section{Acknowledgements}

We would like to extend our appreciation to Hawassa University Comprehensive Specialized Hospital for their support throughout the study period. Also we would like to express our deepest gratitude for study Participants for their unreserved contribution.

\section{Competing interests}

The authors declare that they have no competing interests.

\section{Availability of data}

All analyzed and generated data are included in this article and its supporting document.

\section{Consent for publication \\ Not applicable.}

\section{Ethics approval and consent to participate}

Ethical clearance was obtained from ethical review board of Hawassa University, College of Medicine and health sciences. Ethical issues of the participants were addressed throughout the study. All participants of the study were provided with a written consent, clearly stating the objectives of the study and their right to refuse and if any question they do not want to answer they have the right to do so. All participants were randomly selected without any discrimination on any ground. Filled out questionnaires were carefully handled and all access to results kept strictly.

Funding

No funding was received for this research work.

\section{Publisher's Note}

Springer Nature remains neutral with regard to jurisdictional claims in published maps and institutional affiliations. 
Received: 24 November 2018 Accepted: 17 December 2018

Published online: 20 December 2018

\section{References}

1. Barker LF, Shulman NR, Murray R, Hirschman RJ, Ratner F, Diefenbach WC, et al. Transmission of serum hepatitis 1970. JAMA. 1996;276:841-4.

2. Ozaras R, Tahan V. Acute hepatitis C: prevention and treatment. Expert Rev Anti Infect There. 2009;7:351-61.

3. World Health Organization. Hepatitis B. Fact sheets no 204. WHO Media Center. 2015. http://www.int/mediacenter/factsheet/fs204/en/.

4. Eng-Kiong T, Anna S. Hepatitis B virus vaccination. Up To Date 20.3.

5. Margolis HS, Coleman PJ, Brown RE, Mast EE, Sheingold S, et al. Prevention of hepatitis $B$ virus transmission by immunization: an economic analysis of current recommendations. JAMA. 1995;274(15):1201-8.

6. Weinbaum CM, Mast EE, Ward JW. Recommendations for identification and public health management of persons with chronic hepatitis $B$ virus infection. Hematology. 2009;49(5):35-44.

7. Asfaw NZS, Girmay M. Prevalence of hepatitis B surface antigen (HBs Ag) among visitors of Shashemene General Hospital voluntary counseling and testing center. BMC Res Notes. 2011:4:35.

8. EFMoH. Plan for the introduction of hepatitis $B$ and haemophilus influenza type $B$ vaccines into routine immunization in Ethiopia Addis Ababa. 2005

9. Hutin Y, Hauri A, Chiarello L, Catlin M, Stilwell B, Gebrehiwet T, et al. Best infection control practices for intradermal, subcutaneous, and intramuscular needle injections. Bull World Health Organ. 2003;7:491-500.

10. Geberemicheal A, Gelaw A, Moges F, Dagnew M. Sero prevalence of hepatitis $B$ virus infections among health care workers at the Bulle HoraWoreda Governmental Health Institutions, southern Oromia, Ethiopia. J Environ Occup Sci. 2013;2(1):9-14
11. Djeriri $K$, Laurichesse $H$, Merle $J L$, Charof $R$, Abouyoub A, Fontana $L$, Benchemsi N, Elharti E, El Aouad R, Chamoux A, Beytout J. Hepatitis B in Moroccan health care workers. Occup Med. 2008:58:419-24.

12. Adekanle O, Ndububa DA, Olowookere SA, ljarotimi O, ljadunola KT. Knowledge of hepatitis $B$ virus infection, immunization with hepatitis $B$ vaccine, risk perception, and challenges to control hepatitis among hospital workers in a Nigerian tertiary hospital. Hepatitis Res Treatment. 2015;2015:6.

13. Simard EP, Miller JT, George PA, Wasley A, Alter MJ, Bell BP, Finelli L. Hepatitis B vaccination coverage levels among health care workers in the United States, 2002-2003. Infection Control. 2007;28(07):783-90.

14. Rachiotis GC, Alikakou V, Ferti A, Roumeliotou A. Vaccination against hepatitis B virus in workers of a general hospital in Athens. Med Lav. 2005:96(1):80-6.

15. Pathak R, Chaudhary C, Pathania D, Ahluwalia SK, Mishra PK, Kahlon AS. Hepatitis B vaccine: coverage and factors relating to its acceptance among health care workers of a tertiary care center in North India. Int J Med Public Health. 2013;3(1):55-9.

16. Ouédraogo HG, Tiendrébeogo S, Konseimbo GA, Yetta CE, Tiendrébeogo E, Savadogo AA, Sondo B. Hepatitis B vaccination status and associated factors among health care workers in Burkina Faso. Med Sante Trop. 2013;23(1):72-7.

17. Abeje $G$, Azage M. Hepatitis B vaccine knowledge and vaccination status among health care workers of Bahir Dar City Administration, Northwest Ethiopia: a cross sectional study. BMC Infect Dis. 2015;15:30.

18. Abiola AO, Akodu BA. Knowledge, attitude and practice of hepatitis $B$ vaccination among health workers at the Lagos State accident and emergency centre, Toll-Gate, Alausa, Lagos State. West Afr J Med. 2013;32(4):257-62.
Ready to submit your research? Choose BMC and benefit from:

- fast, convenient online submission

- thorough peer review by experienced researchers in your field

- rapid publication on acceptance

- support for research data, including large and complex data types

- gold Open Access which fosters wider collaboration and increased citations

- maximum visibility for your research: over $100 \mathrm{M}$ website views per year

At BMC, research is always in progress.

Learn more biomedcentral.com/submissions 